\title{
Olay bilimleri ve Hukuk
}

\section{Prof. Süheyp Derbil}

Olay bilimleri. - Olay bilimleri var midur, yani tarih bir bilim midir? Nedense "Tarih" denilince akla yalnız insanlık tarihi geliyor. Bir takım bilginler de bu dar görüşü desteklemiş bulunuyorlar. Meselâ: Profesör G. Monod'ya göre en şümûllü manâsiyle tarih, insanlık tarihidir (1). Profesör Bernheim biraz daha insaflı davranıyor ve diyor ki: "Tarih kelimesiyle, mahdut bir sahaya inhisar etmeksizin, vukubulan hâdisatın nakledilişi ifade edilmek istenir. Onun için bitki tarihi, hayvan tarihi, arzın kabuğu tarihi yanında dẹvletlerin, uluslarm tarihínden bahsedilịr. Hattâ modern tabiî bilgiler ylldızların ve kâinatın tarihini de anlatmıya kalkışrlar. Fakat "Tarih ilmi» ortaya konduğu vakit surf insan dünyasını alâkadar hâdiseler anlaŞllrr.) (2):

Profesör Bernheim'ın niçin, bilim sıfat ve şerefini yalnız insanlık tarihine bağışladığını ve tarihin astronomi, jeoloji, mineraloji, botanik, zooloji gibi kollarına bu şerefi neden esirgediğini bilmiyorum. Bir takım başka bilginler de, bilim olmak şerefini tarihin jeoloji, botanik, zooloji gibi kollarına tanıyorlar da insanlık tarihi koluna esirgiyorlar.

Doğrusu aranırsa: tarih bir bütündür. Eğer jnsanlık tarihi bir bilim ise tabiî tarihin de bir bilim olması gerekir. Bilâkis, tabiî tarih bir bilim ise insanlık tarihinin de bir bilim sayılnıası mantıkî olur. Böyle basit ve açık bir konu üzerinde bir takım derin bilginlerin çelişmelere ( $=$ tenakuzlara $=$ contradictions) düşmeleri eski bilimin etkisi yüzündendir.

(1) G. Monod, Tarihte usul, İstanbul 1938, sayfa 1 de aynen:

"Tarih kelimesini en şümulhü manasında telâkki ederek şöyle târif edeceğiz: tarih, beşer faaliyet ve tasavvuratının - teakup, inkişaf ve irtibat nisbeti (Rapport de connexité) veya tabiiyet nisbeti (Rapport de dépendance) noktai nazarlarından - tecellilerinin heyeti mecmuasıdır." diye yazılıdır.

(2) G. Bernheim, Tarih ilmine giriş, İstanbul 1936 , s. 3 ve 51 . 
Eski bilim doğumdan önce IV üncü yüz yllda başlamış ve doğumdan sonra XVII inci yüz yila kadar hükürm sürmüştür. Eski bilim Sokrat, Eflâtun ve Aristot tarafından kurulan eski Yunan ideacliğına dayanır. Sokrat: "Bilimin konusu evrenseldir.» demişti. Eflâtun evrensele "idea» adını, Aristot ise "öz» adını vermişti. Onlara göre bilimin konusu bu idi. İdealar veya özler yetkin (Parfait =) gerçekliklerdir. Bunlar sürekli idi, ebedì idi, bunların kusurları, düzensizlikleri yoktu. Bunlar bütün varlıklardı. Maddî olmıyan bu tiplerin (ideaların veya özlerin) duyulur gerçekleşmeleri geçicidirler, doğarlar ve ölürler, varlıkları süresince değişirler ve daima yetkinsiz (imparfait $=$ ) ve düzensiz olurlar: Bundan dolayı zekâ bu düzensiz ve geçici varhkları kavrayamaz, belirtemez. Zaman ve uzay içinde beliren varlıklar ve olaylar bilim konusu olamaz, ancak sanı (= zan $=$ opinion $)$ konusu olabilir. Bilim yalnız sürekliye ve düzenliye doğru girer. Olaylarm bilimi olamaz, tarih bir bilim değildir. Eski bịlimin âmentüsü, credosu bunlard1.

Modern bilginler artık bu âmetüye inanmryorlar. Eski çağmn bu metafizik görüşlerini yıkmış bulunuyorlar. Ancak bu yıkılma birdenbire ve bütün olmadığı için bir takım bilginlerin eserlerinde eski bilimin izlerine ve döküntülerine rast geliyoruz. Mesele şudur: Kavrambilimleri (3) gerçek olanlara ve gerçek varlıklara göre degil, bir takım soyutlamalar (= tecridler $=$ abstractions) yapmak, bir takım şartlı durumlar tasarlamak yoliyle evrensel kanunlar belirtirler.

Soyutlama bir basitleştirmedir. Soyutlama ile bir gerçek konunun yalnız bir karakterini veya bir kaç karakterini ele alirız, geri kalan karakterlerini atarız. Bununla kalmayız: ele aldığımız karakterlerin büsbütün arık, büsbütün düzgün olduklarmı farzederiz. Böylece kirpllp yontulduktan sonra konuyu kavrarı. Soyutlamayı en yüksek dereceye çıkaran bilim kolları (matematik gibi) epeyce ilerIemiş, konusu karmaşı olduğu için ancak küçük ö]çüde soyutlama yapabilen bilim kolları ise (sosyoloji gibi) çok geride kalmıştır. Denebilir ki kavram bilimlerinin gelişmeleri yaplan soyutlama ile düz oranlı, konuların karmaşıklığı ile ters oranlıdır. Nekadar çok soyutlama yapılmış - yani gerçeklikten nekadar uzaklaşılmış ise - bilim kolu o kadar gelişmiştir.

Insan zekâsının soyutlamalara dayanan kavram bilimleriyle ye-

(3) Ankara Üniversitesi Hukuk Faküiltesi Dergisi C. 2, Sayı 4 teki aKavram Bilimleri ve Hukuk» yazssina bakulmasi.

Hukuk Fakültesi Mecmuası 3 
tinemiyeceği, gerçek olayları da incelemek istiyeceği meydandadır. Fakat gerçek olaylar o kadar karmaşık, o kadar sayısız ki... Bir bütün olay belirli bir yerde belirli bir zaman içinde gerçekleșmiş vak'aların toplamı değil mi? İsterseniz biraz daha smırlayalım ve "Bir olay, bir varlığı̣ çok kısa bir zaman içinde başından geçenlerdir.» diyelim. Küçük bir varlığın çok kısa bir zaman içinde başından geçenleri gözden geçirelim. Bir kiraz, ağacından koparak yere düşmüsstür. Düşme üç saniye sürmüş̧ür. İşte, çok basit görülen bir olay! Gerçekte o kadar basit degil... "Kiraz yere düz çizgi halinde düşmemiştir. Kirazın ağırlık merkezi tarafından tutulan yol düz çizgi ile gösterilemez. Zaten kiraz ağırık merkezi etrafinda salınmıştır (= raksetnisştir); sağdan sola, soldan sağa, ileriye, geriye ilâh. doğru sallanmış, yalpa vurmuştur. Düşme hareketinin başında bir doku (= nesic) kırılması, sonunda bir çarpma olmuştur. Yere çarpınca kirazm derisi örselenmiş, belki de yarılmış, patlamıştır, deri ile çekirdek arasindaki etli kısım ise bir taraftan yere çarpma dolayısiyle, bir taraftan da çekirdeğin etkisi ile içerden ve dışardan zedelenmiştir. Bu yolculuk sırasında bir takım kimya ve fizik değişmeleri; molekül, atom, elektron hareketleri olmuştur. Ağaçtaki ve meyvalardaki mikroplar ve böcekler çălışmıştır ve ilâh... Bütün bunları nasıl takip etmeli? Vak'alar sayısız değil mi?

Çok küçük bir varlık üzerinde, çok kısa bir zaman içinde cereyan eden vak'aları tamam olarak göremez, bilemez ve sayı dökemez isek, büyük bir olay tümünü nasil tamam olarak inceleyebiliriz? Meselâ: yer yüzünde bitkilerin veya hayvanlarm nasıl belirip geliştiklerini, veya eski çağ, hattâ yeni çağ devletlerinden herhangi birinin nasıl kurulup geliştiğini tam olarak öğrenebilir miyiz? Şüphesiz ki hayır!.. Her şeyi öğrenemiyeceğimiz gibi bütün öğrendiğimizi de bildiremeyiz. Bir olayı anlatmak istiyen kimse bir çok vak'aları bilemez, bildiklerinin de hepsini anlatamaz. Hangi vak'aları inceliyecek, öğrenecek, hangilerini öğretecek, anlatacak? Tarihçinin bütün vak'aları anlatmasuna imkân olmadığına göre anlatacağı vak'aları seçmek keyfine mi kalmıştır?

Hattâ olayları zaman ve uzay bakımlarından sinirlamak da keyfî değil midir? Hangi olay vardır ki kendinden önceki olayların ve başka yerlerdeki olayların etkisi altında kaImaz? O hâlde bilimsel tarih, kusursuz tarih ne zaman ve nerede olursa olsun bütün olaylar1 anlatan evrensel bir tarih olabilir. Böyle uçsuz, bucaksız bir alanda, sonsuz zaman süresi içinde sayısız olayları bize bütün zenginliği, bütün karmaşıklığı ile anlatacak bir tarihi hangi tarihçi yaza- 
bilir? Tarihçi tarihini yazacağı bütün olayların gözlemini kendisi yapabilir mi? Insan, yaptı̆̆ı gözlemlerde yanılmaktan kendini kurtarabilir mi? Hiç bir olay evrende hiç bir değişik durum olmadan bir daha tekrar edebilir mi? Hayır!..

$O$ halde, tarih yarım yamalak olmağa, bir çok eksikler ve gediklerle, bir çok yanlışlarla kusurlu kalmağa mahkûmđur. Kavram bilimlerinin tarihten üstünlüğü bu bakımdandır. Fakat başka bakımdan tarih. kavram bilimlerinden üstün bir durumdadir.

Kavram bilimleri, zekânın gerçekliği daha iyi anlamak isteğinren doğmuştur. Fakat bu isteğimizi doyurmaz. Bilimsel kanunlar gerçeklik değildir. Bilimsel kanunlar mümkün durumlar arasmdaki oranları belirtir. Mümkün durumların gerçeklikle ilgisini incelemek, kavram bilimlerinin konuları dışındadır. Eski Yunan ideacıları, ileri sürdükleri özün veya idea'nm gerçek olduğunu sanıyorlardı. Gẹç̧eğin değişmez ve ebedî olduğuna inanıyorlardı. Bu inanç dolayısiyle biricik bilim çeşidi kavram bilimi olabilirdi. Bu inancm hüküm sürrüğü sıralarda atalarımız, sağ duyulariyle çok doğru bir söz söylemişlerdi: "Çok bilen çok yanılır." demişlerdi. O srralarda bilginler, olayları incelemeği bilim dışında bir iş saydıkları için çok yanılıyorlardl. İşte olay bilimlerinin, yani tarihin kavram hilimlerine üstünlüğü bu bakımdandır. Kavram bilimleri gerçeğe uymaz, gerçeği incelemez ve kavramlarını gerçek sananları yanıltır. Olay bilimleri, olayları incelemek yoliyle bizi gerçeğe daha çok yaklaştırır, bizi yanulmaktan kayırabilir.

Kültürlü bir adam olmak için, gerçeğe yaklaşmak için kavram bilimleriyle birlikte tarihi de incelemek zorundayız.

XIX uncu yüz yılda, eski bilimin tepkisi ile, tarih çok büyük bir önem kazandı. Bir takım tarihçi okullar belirdi. Evrimcilik (= évolutionisme) bu okullardan biridir. Gözlemini doğru olarak yapabileceğimiz olayları incelemeğe önem verecek yerde şimdiki olayların geçmişte ne gibi evrimler sonunda baş gösterdiklerini araştırmak moda oldu. Tabiî pek çok yanlışlıklara düşüldü. Gözümüzün önünde geçen bir olayı bile doğru ve eksiksiz olarak not etmeğe gücümüz yetmezse, bir takım boşluklar ve yanlışlıklar olursa, geçmişteḳi olayları belirtmekte nekadar yanılacağımız çabuk anlaşılır.

Bununla beraber, tarihte nekadar yanılırsak yanılalım; bilimden maksat gerçeği anlamak, gerçeğe yaklaşmak ise tarih, kavram bilimlerinden üstün tutulmalıdrr.

Tarihin konusu. - İdeal tarih, bütün tarih bize her şeyi anlatacaktır. Fakat tarih eksiksiz olamaz. Tarihçi bile bütün öğrendiklerini 
anlatmağa kalkışamaz, seçim yapar, bir takım bildiklerini çıkarır. Tarih için her bir boşluk, her bir seçim ve çıkarma şüphesiz bir kusurdur. Fakat bu kusurlardan sakınmak imkânı yoktur.

Tarihçi belirteceği olayları nasıl seçer? Nasıl seçmelidir? İlk önce önemle değeri ayırdetmelidir. İncelenen tarih koluna göre bir takım olaylar önemli veya önemsiz olabilir. Süveyş kanalını açılması Ticaret Tarihi için önemli, Edebiyat tarihi için önemsiz olabilir.

Değer ise, adamina göre değişir. Aldığımı eğitimin, geleneklerimizin, yaşımızın, beden yapımızın ve ilâh... düşüncelerimiz üzerinde etkileri olur. Bu etkilerden kendimizi sıyıramayız. Ancak olaylarını analtmakla yetinir veya savaş̧̧ı olduğu için vak'aları ballandıra, birbirinden kolaylikla ayırdedilebilir. Fakat, bir savaşı tarihini yazan bír kimse barış̧ı olduğu için savaşın yalnız en ackklı vak'alarnı anlatmakla yetinir veya savaş̧̧ı olduğu için vak'aları ballandıra, ballandıra anlatmağa çalışırsa görevini gereği gibi yápmamış olur (4).

Sik görülen olaylar mı daha önemlidir, yoksa seyrek olanları mı? Şüphesiz ki sık görülenler daha önemlidir. Fakat bir çok tarihçiler, çok seyrek görülen olayları belirtmeğe özenirler de sık görülen olayların sözünü bile etmezler.

Böyle davranışlarını ulu ortá kötülemek doğru olmaz. Tarihçi, bir çok olayları okuyucularını bildiğini farzeder, onlara bilmediklerini anlatmakla yetinerek sözü uzatmaktan sakınır. Şüphesiz her yıl tarlaların, ağaçların yeşillenmesi, başakların sararması, meyvaların olgunlaşması, krrk yılda bir deprem olmasından çok daha önemIi bir olaydır. Bunun gibi, her gün insanların işleri başına koşmaları, çalışmaları, çabalamaları kırk yılda bir savaşa girmelerinden çok daha önemlidir. Ancak, sık sık tekerrür eden bu önemli olaylar gözümüzün önünde geçtiği için tarihçi bunları anlatmaktan çekinir, deprem gibi. savaş gibi olayları - seyrek oldukları için — daha az önemli olsalar bile, herkes tarafından iyi bilinemiyeceği için anlatır.

Bundan başka, tarihçi kitabını, okuyucularının bilgi seviyesine göre yazar. Tarih kitaplarında bir çok noktalar örtïlü geçilir. Örtülü geçilen noktaları okuyucu bilmiyorsa tarihi iyi anlatamaz. Yanlış biliyorsa tarihi de yanlış anlayabilir, ancak doğru bildiği takdirde iyi ve doğru anlayabilir.

(4) Muhtelif memleketlerde resmî okullar için kabul edilen tarih kitapları arasında bir kıyaslama yapmak çok öğreticidir. Aynı olay bu kitapların birinde başka türlü, ötekinde başka türlü anlatılmıștır. Olayın yeri ve olayla ilgili kimselerin adları belirtilmiş olmasa, insan, başka başka olayların anlatıldığını sanacak. 
XIX uncu yüz yılda patlak veren bir savaşın tarihini yazarken birbirleriyle çarpışan orduların hiyerarşiye bağlı oldukların, erlere, erbaşlarm, erbaşlara subayların emir verdiklerini, subaylarm da daha yüksek rütbeleri subaylardan, bunların da daha yükseklerinden ve ilâh... emir aldıklarını ve nihayet hepsinin bir baş komutanın emirlerine bağlı bulunduklarını anlatmaz. Bunu okuyanların bildiklerini farzederek vak'aları anlatmağa başlar: Okuyanlardan bunu bilmiyenler meseleyi iyi anlayamaz, yanlış bilenler ters anlayabilirler, ancak doğru bilenler doğru anlayabilirler. Tarihçi, kitabmı okuyacak kimselerin bunları bilemiyeceğini düşünürse bunlan da anlatması gerekir.

Modern tarih, yalnız olayları suralamakla yetinmek istemiyor, olayları anlamağa ve açıklamağa da çalışıor.

Olayların incelemesi, anlanması, anlatılması, açıllanmsı, olaylardaki düzenliklerin veya düzensizliklerin belirtilmesi tarihin konusu içindedir. Bu bakımdan astronomiyi olay bilimieri içine, yani tarih içine 'almak gerekirken $\mathrm{A}$. Comte tarafından kavram bilimleri arasında sayılmıştır. Bu bulanıkIığın sebebi evrensel kanunlarla tabiat kanunlarınm birbirine karıștırılmasidır (5).

Pek çok bilginler Kepler kanununun Newton'un' "evrensel çekim kanunu” (la loi de gravitation universelle $\Rightarrow$ ) ile açılandiğını, Newton Kanunundan çıtığını bildirirler. Halbuki Newton'un kanunu bir bilimsel kanundur, evrenseldir. Kepler'in bildirdiği ise tarih içinde yer alacak bir olaydır, nihayet bir tabiat kanunu olabilìr.

Meseleyi açiklamak için; ilk önce Newton kanununu inceleyelim. Newton cisimlerin birbirini çektiklerine inanmadığını açıç̧a belirtiyor ve şartlı bir durumdan hareketle bu şartlı durumun zorunlu' sonucunu bildiriyor. Newton kanunu şudur:

$\mathrm{Ne}$ olduğunu bilmediğimiz bir sebep dolayısiyle, eğer boşlukta iki cisim yalnız başlarına ve duraklama halinde bulunurlarsa ve yal-

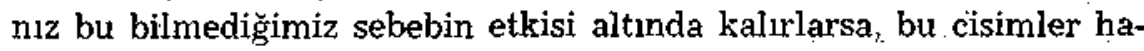
rekete geçerler ve birbirlerine doğru düz çizgi doğrultusunda yaklaşrlar. Hızları kütleleri ile cisimlerin birbirinden uzaklığına göre değişir. Eğer iki cisim yerine üç cisim bulunursa yine birbirlerine yaklaşırlar, fakat hareketleri düz ve basit olmaz.

Eğer başlangıçta cisimler duraklama halinde değillerse, sayıiarı çoksa ve ne olduğunu bilmediğimiz halde "çeki» adını verdiğimiz

(5)Evrensle kanunlarla tabiat kanunlart arasindaki fark, bu derginin geçen sayısındaki «Kavram bilimleri ve Hukuk» başlıklı yazımda belirtilmiştir. 
sebepten başka sebepler de etki yaparlarsa, dairese], eliptik hareketlerle ayrılma, dağılma, uzaklaşma gibi çeşit çeşit hareketler baş gösterir.

Görülüyor ki Newton gerçek hiç bir olayı incelemiyor. Bilâkis, bir takım şartlı durumlar ele alıyor ve bunların zorunlu sonuçlarının ne olacağını bildiriyor. Tam manasiyle bilimsel ve evrensel kanunlar belirtiyor. Bu şartlı durumların bir kısmının gerçekleşmesine imkân yoktur. Boşlukta yalnız başlarına duraklama halinde iki veya üç cismin bulunması ve bu cisimlerin başka hiç łir sebebin etkisi altında bulunmaması, içinde bulunduğumuz evrende imkânsızdır. Çünkü evren sayısız cisimlerle doludur. Yani bu teoremi denemeğe imkân yoktur.

Newton'un teoremi gerçek olaylardan nekadar uzaksa, Kepler'in bildirdiği nesne, gözlemi yapılmış olayların açı bir ifađesidir. Kepler bize güneş etrafinda dönen ylldızlarm yürüngelerini ( = mahreklerini $=$ orbite), hizlarmı bildirmektedir. Burada ne teorem, ne şartlı durum vardır. Burada sadece gerçek olayla:, düzgün olaylar vardir.

Bir olayın düzgün olması, yani belirli sürelerde veya belirli yerlerde tekerrür etmesi, o olayın akışını bildiren sözün bir kanun olmasinı gerektirmez.

"Her yedi günde bir resmî daireler kapalı kalır.., "Posta müvezzileri her gün mektupları̣ dağıtır», "Her köyün bir ınuhtarı vardır.", "Her ilin bir valisi bulunur.», "Bütün kuşlar ve iütün memeliler sıcak kanlıdır.", "Güneşin etrafındaki bütün yıldızlar ve yıldızcıklar (asteroit $=$ ) batıdan doğuya doğru dönerler.) (5) cümlelerini birer bilimsel kanun telâkki etmek saçma olmaz mı? Kepler'in söylediği de bunlara berizemiyor mu? (6).

Eski ideaclığa göre düzenlik değișmez bir gerçekliktir. Düzensizlik maddenin özüne uymamasından ileri gelir. Modern bilinin

(5) Herbert Spencer, Classificatin des sciences, Paris 1923, sayfa g.

(6) Felseféde zorunluluk (zaruret $=$ nécessité $=$ ) ve olumsallık (imkân = Contingence $\Rightarrow$ sözlerini sik s1k kullanırlar. Biz de bu iki terimden faydalanarak diyebiliriz ki bilimsel kanunlarda belirtilen sonuçlar zorunludur. Başka, türlü olamaz. Meselâ: her hukukun bir etkin ve bir edilgin öznesi vardır. «Baska türlü olamaz. Etkin veya edilgin öznesi bulunmiyan hukuk yoktur ve olamaz. Yukardaki cümlelerde belirtilen sonuçlar zoruniu đeğil, olumsaldır. Meselâ: *bütün kuşlar sıcak kanlıdır.» diyoruz. Bütïn kuşların sıcak kanlı olması zorunlu đeğgildir; olumsaldır. Günün birinde soğuk kanlı bir kuşun bulunması imkkânsız değildir. "Güneşin etrafındaki bütün yıldızlar ve yıldızcıklar batıdan 
böyle bir açıklamayı kabul etmesi beklenemez. Bugünkü anlayışa göre olaylar sayısız sebeplerin etkisi altmdadir. Bu sebeplerden bir kısmı süreklidir, bir kısmı geçici olabilir. Olaylar üzerinde sürekli sebeplerin etkileri nekadar büyük olursa olaylarda o kadar düzenlik görülür. Geçici sebeplerin etkileri nekadar büyük olursa ve hele bu sebelper başka başka doğrultularda etkiler yaparlarsa olaylarda o kadar çok düzensizlikler görülür. Yıldızların haceketi, sürekli sebeplerin etkisi altında olduklarından, düzenlidir. Akan yldızlarm (= şehabı sakıp = étoile filante) hareketleri ise, bir takım geçici sebeplerin etkisi altında kaldığından düzensiz olur.

Tarihte olaylaṛı bir önceki olayla açıklarız. Ónceki olayı olduğu gibi kabul ederiz. Onu da açıklamak ihtiyacm duymayız. Böylece, açıklanmamışa dayanarak açıklama yaparız.

Hastalıkh, culı, sinirli bir çocuk görünce bunun sebebini araştırırız. Babasının ayyaş olduğunu öğrenince artık bununla yetiniriz. $\mathrm{Bu}$ bilgi bize çocuğun niçin cllız ve sinirli olduğunu açıllar, fakat, cocuğun babası niçin ayyaştı? Artık bunu araştırmayız. Araştırsak bile bu yoḷda uzun boylu devam edemiyeceğimizi, ergeç çımaza saplanacağımızı biliriz. Kavram bilimleri gibi tarihin de başlangıcı esrarla örtülüdüir.

Tarihin önemi: Bir çok bilginler, kavram bilimleri arasında yer alan kolların olay bilimleri arasında artık yeri olamıyacağı veya olay bilimleri arasında yeri olan bir kolun artık lsavram bilimleri arasında yer alamıyacağı kuruntusuna kapılmışlardır.

Meselâ: Herbert Spencẹ bilimleri şöyle smifliyor:

\begin{tabular}{|c|c|c|c|}
\hline $\begin{array}{l}\text { Olayların bize görüdü̧üin şekil- } \\
\text { leri inceleyen bjlimler }\end{array}$ & $\begin{array}{l}\text { Soyut bi- } \\
\text { limier }\end{array}$ & Mantik & atik \\
\hline $\begin{array}{l}\text { Olayların kendisini inceleyen } \\
\text { Bilimlerden }\end{array}$ & $\begin{array}{l}\text { Olaylarjn } \\
\text { unsurlarunı } \\
\text { bilertenler }\end{array}$ & $\begin{array}{l}\text { Soyut } \\
\text { Somut } \\
\text { bilimler }\end{array}$ & $\begin{array}{l}\text { Mihanik, Fizik } \\
\text { Kimya ve saire }\end{array}$ \\
\hline . & $\begin{array}{l}\text { Olaylarun } \\
\text { tümünü be- } \\
\text { lirteuler }\end{array}$ & $\begin{array}{l}\text { Somut } \\
\text { bilimler }\end{array}$ & $\begin{array}{l}\text { Astronomi, Je- } \\
\text { oloji, Ruh bj- } \\
\text { lim, Sosyoloji } \\
\text { ve sajre }\end{array}$ \\
\hline
\end{tabular}

doğuya doğru dönex.» diyoruz. Bu da zorunlu değildir; olumsaldır. Günün birinde doğudan batıya doğru dönen bir yıldızetk keşfedilemiyeceğgi ne mâlûm?... Nitekim Avusturalyanrn kesfinden önce tabiat bilginleri: «bütïn Kuğg kuşları beyazdır.» diyorlardı. Bu da zorunlu bir sonuç deģildi. Avusturalya keşfedilince, bu kıt'ada siyah kuğu kuşları bulundu ve tabiat bilginlerinin bu önermeleri de suya düştü. 
$\mathrm{Bu}$ sinfflamada astronomiyi somut bilimler arasina almakla $\mathrm{A}$. Comte'den fazla anlayış göstermiş olduğu söz götürmez. (7).

Ancak Spencer de bir bilim kolunun yalnı bir yönden incelenebileceği düșüncesine saplanmiștır. Bu yanlış düşünce ile Spencer artık sosyoloji kolu kurulmuş olduğuna göre ayrıca insanlık tarihi olamıyacağını, insanlık tarihinin sosyoloji içinde olduğunu ileri sürmeğe kalkişmıştir.

Tekrarlamağa lüzum yok ki: kavram bilimi olarak bir sosyolojinin bulunması, olay bilimi olarak ayrı bir sosyolojinin varlığına engel olamıyacağı gibi, bunun varlığı insanlık tarihinin ortadan kalkmasını da gerektirmez.

Kavram bilimi olarak sosyolojide bir takım teoremler belirtilir. "Bir topluluk içinde yaşayan insanların Kamul inançları kalmazsa bu topluluk dağılır.) önermesinde olduğu gibi. Olay bilimi olarak incelenen sosyolojide bir takım genel olaylar belirtilir. A. Comte'm üç hal teorisi gibi. Ửç hal teorisi bir sentezdir. Insanlık tarihi ise bir analizdir. Bu üç nesneden hiç biri ötekinin yerini tutamaz. Ancak, insanlık tarihi, olay bilimi olarak sosvoloijye, bu da kavram bilimi olarak sosyolojiye hizmet ve yardm edebilir. (8).

Hukukta da böyle değil mi? Kavram bilimi olarak hukukta bir takım genel olaylar belirtilir: "Oırsızlığı fizik müeyyede ile cezalantıli olur. Ne mutiak, ne de bağıntılı olmiyan huikuk olamaz." gibi bildirilen bu sonuç zorunludur. Olay bilimi olarak hukukta ise bir takım genel olaylar belirtilir: «Hursızlığı fizik müeyyede iłe cezalandirmayan bir devlet yoktur., sözünde olduğu gibi. Fakat burada zorunlu bir sonuç yoktur. Hırsızlığı cezalandırmıyan bir devlet olabilir.

(6) H. Spencer, adı geçen eseri, S. 6.

(7) A. Comte, astronomiyi soyut bilimlerden saymtş ve matematiğin yanina koymuștur.

(8) Fakat bunu bilen, anlayan, düşünen sosyoloğlar nerde? Duprat'nın eserini görmeseydim bilimsel bir sosyoloji kurmak için henüz hic bir şey yapılmamış olduğuna hükmedecektim. Sosyoloji kitaplarını ve dergilerini dolduran yazılar (büyük bilgin Pareto'nun kitabı da dahil olduğg halde) hemen baș$\tan$ aşağı tariki ilgilendirmektedir: İnançların nasıl geliştikleri ve nasıl değiştikleri, âdetlerin, estetik yönsemeletin, iktisadî hareketlerin tarihi ve saire... sosyoloğlar, sentez yapmak gaysetile, gözlemlerini genelleştiriyorlar ve böylece sosyolojinin . kanunlarmm belirttikleti kuruntusuna kapiliyorlar. Pareto ise yapılan bir çok genellemelerin yanlış olduğunu. olayların buniarı yalanlađığını anlatmış durmuş. 
Fizikte de böyledir. Helmholtz adında bir fizikçi, aşă̆ı yukart şunları yazmıș: "Evrende bulunan enerji hiç bir olay dolayısiyle azalamaz veya çoğalamaz.» Bu fizikçi, şüphesiz ki; evrende bulụan enerji miktarmın insanlar tarafından ölçülebileceğine ve fizik biliminin bu enerjiyi bir rakamla ifade edebileceğine inanmış değildir. Bu önermesi olsa olsa bir tarih varsaymı $(=$ hypothèse $=\mathrm{fa-}$ raziyesi) olabilir.

Kavram bilimi ile olay bilimi arasindaki farkı belirtmek için şu teoremleri yazalım:

Fizik teoremi: enerji şekil değiştirmeklè artmaz ve eksilmez. Tarih teoremi: gerçek bütün olaylar, enerjinin şekil değiştirmesinden ibaret olduğu için gerçekte enerji niceliğinde (= quantité = kemiyetinde) ne artma, ne de eksilme olur.

İkinci teoremde bir zorunluluk yoktur. Hattâ olayların gereği gibi incelenmesi bu tarih teoremini belki de bir gün çürütebilir. Nitekim Bergson, Helmholtz'un bu tarih teorisini çürütmüş've yerine "yaratıcı evrim" (= évolution créatrice =) teorisini önermiştir. Ë̆ger evrim yaratıcı ise enerji yaratıyor, yani enerji artıyor demektir. Helmholtz'a göre yaratma ( $=$ création) gibi görünen olaylar gerç⿳亠丷厂巾kte birer dönüşüm (transformation $\Rightarrow$ ) dur. Bergson'a göre ise dönüşüm gibi görünen bir çok òlaylar gerçekte birer yaratmadır. Böylece tez ile antitez çarpışmaktadır. Böyle bir çarpıșma olay bilimlerinde görrülebilir.

Enerji dönüşümü ve enerji yaratımı teorilerinde olduğu gibi, enerji alçalımı (dégradation de l'énergie $=$ ) teorisinde de kavramla tarihi ayırdetmenin öremi büyüktür. Şöyle ki:

Isı ile mihaniki iş elde edilix Kazandaki buhar, pistonu harekete geçirir. Fakat pistonun harekete geçmesi için buharın sıcak olması yetişmez, pistonun öteki tarafından daha sıcak olması gerektir. S1caklıkları eşit iki kazan arasına konan bir piston - kazanlardaki buhar nekadar 1sitılırsa isitılsın -- hareketsiz kalır. Mihanikî iş elde etmek için sıcaklık farkı gereklidir. Hâlbuki sıcaklrklar ışı̣ma (= rayonnement $=$ inșia') ve iletme $(=$ conduction $=$ nakil $)$ ile eşitlenir (s'égalisent $\Rightarrow$ ) eşitliğe doğru bu ilerleyişe fizikçiler "entropinin artmasio (augmentation de l'entropie $=$ ) diyorlar.

Fizikçilere göre evrende entropi artıyor, sıcaklıklar eşitleşiyor ve bu yüzden, enerji niceliği değişmediği halde, iş gücü (puissance de travail $\Rightarrow$ ) azallyor. Enerji alçalıyor. Dünya durgunluğa, hareketsizliğe doğru yürüyor. Lord Kelvin bize evrensel uyku ve ölüm 
haberini veriyor. Gerçekte öyle midir? Öyle sanyorum ki, bunu Lord Kelvin'in de bildiği yok. Evrende yalnız ısı farklarının azaldığ̀ mi görüyor? Arttığ́l görülmüyor mu? Şimşek çakınca, iki yıldız veya yıldızcık birbirine çarpınca (9) ve nihayet - atom bombasinda olduğu gibi — atom dağılınca, hattâ bir takım kimyasal birleşmeler olunca ısı artmiyor mu? Isı farkı çoğalmıyor mu? Le Châtelier kanunu ne güne duruyor? Kara haberci Lord'mu hakl1, yoksa eyimser karşınları mı? Bilmiyorum! Ancak bilimsel teoremle, tarihsel tezlerin ayırdedilmesi gerektiğini bir daha belirtmek yerinde olacak.

Bilimsel teorilerde bir şartì durum ele almır. Önermelerinde daima açık veya gizli bir şart bir "eğer", bir “ise» vardır. Enerji alçalımı teorisini ilk önce fizikçi Sadi Carnot ortaya koymuş ve: Yalit (mücerret $=$ isolé) bir sistemde mihanikî güç azalır." demiștir. İşte bütün bilimsel kanunlardaki șartlı durum, gizli "eğer" ve "isen!.. "Eğer bir sistem yalit ise iş gücü azalır.» dersek şartlı durumu açığa vurmuș oluruz. İmdi, evrenin bir yalit sistem olduğunu iddia etmeğe hakkımız olmadığına göre, Carnot'un fizik kanunundan Kelvin'in tarihsel tezi çlkmaz:

Fiziłikte olduğu gibi biyolojide de kavram bilimini, olay biliminden yani tarihten ayrdetmelidir. Biyoloji kolunda kavram bilimi konusuna girebilecek evrensel kanunlar pek azdır. Ruhbilim de böyledir. Halk psikolojisi, ferd psikolojisi, orta çăg psikolojisi gibi konular üzerinde yapilan incelemeler birer tarih incelemesinden başka bir şey değildir.

Hukuk da böyle değil mi? Bir çok hukuk bilginleri: bir kavram bilimi olarak hukuk var mıdır? Bunu düşünmemişlerdir bile. Hukuk bilimi adin vererek yaptıkları incelemeler birer tarih incelemesinden başka bir şey değildir.

Ayırd yapabilmek için şu cümleleri ele alalım:

1. - Her devlette idare eden ve idare edilen kimseler vardrr.

2. - Modern devletler bir takım idarî taksimata ayrılırlar.

Birinci cümle kavram bilimini ilgilendiren evrensel bir kanundur, zorunludur. Sartl bir durumun zorunlu bir sonucudur. Nerede ve ne zaman olursa olsun bir devlet varsa mutlaka ve daima idare eden ve idare edilen kimseler vardır. Başka türlü olamaz.

(9) Gökte yıldızların vo yıldızcıklatın birbirlerine çarparak birleșmeleri olağan ișlerdiendir. Böylece, ışildamadıkları için, teleskopla görülmeyen yılđızlar birbirlerine çarpınca ışılđamıya başlıyor:ar, götünüyorlar. Bụ 1şıldamalar bazen haftalarca, hattâ aylarca sürüyor. 
İkinci cümle kavram bilimini ilgilendiremez, olay bilimini yani tarihi ilgilendirir. Zorunlu değildir; evrensel değildir. "Nerede ve ne zaman olursa olsun her devlet mutlaka ve daima bir takım idarî taksimata ayrılır." demek doğru olmaz. Eskiden bir tek şehirden ibaret bağımsız devletler vardı. İkinci cümle tarihsel bir genellemedir.

Bilginlerin yazdıkları bilimsel hukuk kitapları, böyle tarihsel genellemelerle doludur. $\mathrm{Bu}$ genellemeler bir çok çözümlemeler ( = tahlillere analyses) den sonra yapllır ve böyle yapılmalıdır. Meselâ: Türkiyenin bir takım illere, ilçelere, İngilterenin bir takım kontluklara ve distriklere, Fransanin bir takum departımanlara ve arrondismanlara ilâh... ayrıldıklarını görüyoruz. Şimdiki devletler arasında bir takım idarî taksimata ayrılmamış olanı gözümüze çarpmıyor. Bu çözümlemelere dayanarak: "Modern devletler bir takım iđarî taksimata ayrilırlar.n genellemesini yapiyoruz.

Kavram bilimlerinin konuları soyuttur. Geometrideki şekiller nasıl soyutsa, arik hukuk biliminde ele alınan kavramlar soyuttur. Fizik, aritmetiğin değer ve büyülük kavramlariyle geometrinin şekil kavramina yalnız madde ve kuvvet kavramlarını ekler; o kadar. Başka bir şey eklemez. Biyoloji, fizik kavramlarına yalnız hayat kavramın, ruhbilim bunlara yalnız ruh kavramını, sosyoloji ise öncekilere topluluk (10) kavrammı ve nihayet hukuk, kavram bilimi olarak hukuk, sosyolojiye müeyyede (11) kavrammı ekler.

Tarihin konusu ise somuttur. Bütün olaylarla, bütün varlıklarla ilgilenmek zorundadır. Olaylar ve varlıklar ise karmaşık ve sayısızdır. Insan ömrü ne bunları incelemeğe, ne de öğrenmeğe yetişir. Hepimiz, tarihi öğrenmeden hayata gözümüzü yummak durumundayız. Şu kadar var $\mathrm{ki}$, içinde yaşadığımız şartları ve durumları bize ancak tarih aydınlatabilir; tarih açılar.

Eskiden yalnız insanların değiştiği, geliştiği samllyordu. Hayvanlarm oldukları yerde saydikları kuruntusu vardır. Bu kuruntuyu XIX uncu yüz yılda Lamarck ve Darwin ortadan kaldırmiştır. Artık hayvanların da evrime bağlı oldukları anlaşılmıştır. Copernic'e gelinceye kadar, hattâ Copernic tarafından inorganik varlıklarm de-

(10) Insan ve hayvan toplutukiari. Sosyolojinin konusu evrensel olablimek için genel olmalıdır; yalnız insan topluluklarını değil hayvan topluluklarını da incelemelidir.

(1) Felsefe terimleri arasında (sanction) kelimesine karşılık (yaptırım) kelimesi kabul olunmaktadir. 
ğişmezliği inancs ileri sürülüyordu. Bu yanlıs inancı Kant ile Leplace düzeltmişlerdir. Bütün bu düzeltmeler olayların incelenmesi sayesinde, tarih incelemeleri yoliyle yapılabilmiştir.

Bugün, organik varlıklar, yer yüzündeki sularm epeycesini özümlemiş bulunuyor. Organik varlıklarm pek az clduğu devirlerde kasırgaların şimdikinden çok dehşetli ve yıkıcı olduklarına şüphe yoktur.

Son yüz yıl içinde de büyük endüstrinin ilerlemesi, kömürün geniş ölçüde kullanılması, havanın kömür zerreleriyle dolmasina sebep olmuştur. "Beyaz kömür adıni vedikleri akar sudân elektrik kuṿveti çıkarmak yolu bulunmasaydı belki de, insan içirı ancak ormanlarda yaşamak imkânı kalacak, şehirlerde, fabrikalar civarında hava teneffüs edilmez hale gelecekti.

Bütün bu bilgilerimizi tarihe borçluyuz. Bilgimiz arttıkça tarihin alanı da genişlemektedir.

Bu ucsuz, 'bucaksız bilim alanını bir takım sentezler yapmak yoliyle kavramağa çalışıyoruz. Hukuk fakültelerinin hemen bütün kürsülerinde insanllk tarihi inceleme konusudur. Yalnız Hukuk tarihi veay Roma Hukuku Profesörleri değil, Medenî Kanunun veya Ceza Kanununun bir hükmünü açılıyan Profesör, bir Mahkeme içtihadını belirten Profesör, Devletçiliğin veya liberalliğin etkilerini anlatan Profesör ve ilâh... hep tarih incelemeleri yapıyor, insanlik tarihini inceliyor demektir.

Insanlık tarihinin incelenmesi bir çok güçlüklere çarpıyor! Insanlar bilinçli varlıklardır, bir takım amaçlar güderler, bir takım araçlar seçerler, çeşitli topluluklar halinde birleşirler, çeşitli kurallariyle davranışlarını düzenlerler. Insanlık tarihini aydinlatacak esaslar ruhsal kanunlarla toplumsal kanunlardir. Bu kanunlar ise pek az biliyoruz.

Bundan başka, ruhsal olayların gözlemini ne bilginler, ne de tarihçiler yapabiliyor. Her bir insan kendi ruhsal durumunu, kendi ruhsal durumundaki değişiklikleri doğrudan doğruya biliyor ama yalnız kendi ruhunda geçen olayları biliyor. Başkalarının içinden geçenleri, davranışlarına, sözlerine, yazılarına gö̀e yorumluyoruz. $\mathrm{Bu}$ yorumlamalara güvenilemiyeceği meydandadır. Bir takım tarih kitaplarında: "Falan kimse şunu yapmak istiyordu." Meselà: "Fatih Istanbulu almak istiyordu.", "Vaterloda birinci Napolyon yenilgeye uğramaktan korkuyordu." gibi sözlere tesadüf edilir. Gerçekten Fatih istiyor muydu? Napolyon korkuyor muydu? Binu pekin olarak 
kimse bilemez. Bu gibi iddialar birer yorumlamadan fazla bir değer ifade edemez. (12).

İşte, kavram bilimlerinde olduğu 'gibi, ol ay bilimlerinde de bir noktaya kadar ilerledikten sonra aşılmaz engeller karşısında duraklamak zorunda kaliyoruz.

İnsan - iki tavşan arkasında koşan bir aveı gibi - iki amaç peşinde koşmakta ve çabalamaktadır. Bu iki amaç: hakikat ve mutluluktur.

Hakikat sevgisi ve mutluluk çekisi!.. İşte insanı çalıştıran iki büyük dürtü $(=$ muharrik $=$ mobile $)$ !

Hakikati bulmağa, öğrenmeğe çalışıyoruz. Hakikat başlı başına bir amacimız oluyor.

Hakikat bir araç da oluyor. Hakikate yaklaşmca seviniyoruz. Hakikate yaklaşmak başlı başına bir mutluluk aracı oluyor. Bununla da kalmıyoruz: Hakikatlerden mutluluğumuzu artıracak, yaşayışımızı iyileştirecek çareler çıkarabileceğimizi de umuyoruz. Bunun için de, bir araç olarak da hakikati seviyor ve kovallyoruz.

Hakikate yaklaşmamı̣ı kolaylaştıracak, hakikati yanlıştan ayırdetmeğe ve bizi mutluluğa ulaştırmağa yarayacak bilgileri de kural bilimleri kolunda buluyoruz. İleriki yazımıda kural bilimleri arasında "Hukuk» yerini belirtmeğe çalışacağı.

Prof. Süheyp Derbil

(12) Sözlerimiz, davranı̧̧larumı, yazılarımız. düşüuncelerimizi, duygulamız, isteklerimizi belirtmeğe yaræăiğı gibi gizlemeğe, başkaların aldatmağa da yarayabilir. Bir takım korkak kimseler surmus gibl, üzüntiullï kimseler slvinçli imiş gibi, istekli kimseler, isteksizmiş gibi davranamazlar mt? 